\title{
Skin Soothing Effect of Three Herbs from the Namwon-Mt.Jiri Regions
}

Jiwon Han, Bomi Nam, Seyul Kim, Yuna Park, Beom Seok Lee, Ji Young Hwang*

Institute of Natural Cosmetic Industry for Namwon, Namwon-si, Jeollabuk-do, Korea

*Corresponding author: Ji Young Hwang, Institute of Natural Cosmetic Industry for Namwon, Namwon-si, Jeollabuk-do 55801, Korea

Tel.: +82636338603

Fax: +82636338605

Email: hjyhjy123@ncn.re.kr

Received August 31, 2021

Revised October 12, 2021

Accepted October 29, 2021

Published December 30, 2021

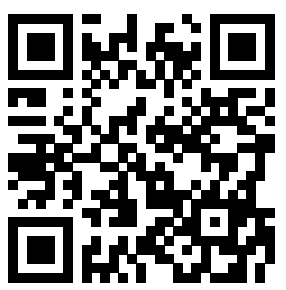

\begin{abstract}
Purpose: This study was conducted to evaluate lavender, lemongrass, and peppermint grown in the Namwon-Mt.Jiri regions as functional soothing ingredients for cosmetics. Methods: The simultaneous analysis of 19 polyphenols in 50\% ethanol-extracted samples of lavender, lemongrass, and peppermint cultivated in the Namwon-Mt.Jiri regions were analyzed by high-performance liquid chromatography (HPLC). Antioxidant activity was measured using 2,2-diphenyl-1-picrylhydrazyl (DPPH). Using real-time PCR, improvements in skin barrier function were confirmed by observing the mRNA expression levels of filaggrin and involucrin, and the moisturizing ability was confirmed through the mRNA expression of HAS-2 and HAS3. The anti-inflammatory efficacy was verified by confirming the expression levels of the inflammatory cytokine IL-6 and the pro-inflammatory mediator nitric oxide (NO). Results: In the simultaneous analysis of 19 phenolic compounds, rosmarinic acid from lavender; chlorogenic acid, syringic acid, p-coumaric acid, and ferulic acid from lemongrass; and caffeic acid, quercitin hydrate, rosmarinic acid, and hesperetin from peppermint were identified. Antioxidant efficacy was confirmed by DPPH radical scavenging, and excellent efficacy was shown in the order of lavender, peppermint, and lemongrass. Filaggrin and involucrin, skin barrier-related genes, were increased more in lavender, lemongrass, and peppermint than in the untreated group. HAS2 and HAS-3 were also confirmed to be increased in lavender, lemongrass, and peppermint. Lavender, lemongrass, and peppermint all showed concentrationdependent inhibition of IL-6 and NO. Conclusion: Extracts of lavender, lemongrass, and peppermint cultivated in the Namwon-Mt.Jiri regions had excellent antioxidant, skin barrier, moisturizing and anti-inflammatory effects, so may be considered for use as natural raw materials for soothing cosmetics.
\end{abstract}

Keywords: Lavender, Lemongrass, Peppermint, Skin-soothing, Anti-inflammation

\section{Introduction}

최근 코로나바이러스감염증-19(COVID-19)로 인한 마스크 착용 의 장기화와 자외선, 미세먼지, 공해, 기후 등의 exposome, 즉 환경 적인 요인으로 인한 피부의 이상반응이 일어나는 사례가 늘어나고 있 다. 다양한 원인으로 인한 피부이상반응은 여드름, 발적, 가려움 순으 로 많이 나타나며, 특히 여드름은 mask와 acne의 합성인 'Maskne' 라 는 신조어를 형성할 정도로 최근의 특정한 환경 아래에서 일어나는 피 부 트러블을 호소하는 일들이 늘어나는 추세이다. 이렇듯, 이상반응의 대부분을 차지하는 여드름, 발적(홍진), 가려움 등의 증상을 극복하는
'진정'은 화장품의 대표적인 효능으로 알려져 있으며 오늘날의 환경적 인 요인과 더불어 chemical phobia와 맞물려 진정 효능을 가지는 천연 물에 대한 소비자의 수요가 급증하는 추세이다.

한편, 피부는 미생물, 자극물질, 오염물질, 미세물질과 같은 외부 유입 물질로부터 우리 몸을 지키는 장벽의 역할을 수행한다(Forslind, 1994). 피부는 표피, 진피, 피하지방층으로 구성되어 있으며 표피는 각화과정에 따라 각질층, 투명층, 과립층, 유극층, 기저층으로 나뉘 어진다. 표피세포의 대부분은 각질형성세포이며(Rawlings \& Matts, 2005), 각질형성세포는 filaggrin과 같은 단백질을 발현하여 피부 장 벽을 형성하고(Sandilands et al., 2009), 히알루론산을 만들어내는 
hyaluronic acid synthase를 생성하여 보습에도 관여한다(Pienimaki et al., 2001).

피부 외부에서 자극이 발생하게 되면, 자극에 의해 피부에서 활성 산소의 양이 증가하게 되는데, 항산화 효능을 가진 천연물의 경우 1 차적으로 활성산소의 농도를 낮춰주어 외부의 자극을 완화하는 효능 을 가진다. 항산화 효과로 활성산소의 농도를 낮추는데 성공했다 하더 라도, 지속적인 자극이 주어지게 되면, 이는 피부 장벽의 손상으로 이 어진다(Lin et al., 2018). 각질층이 손상되면 필라그린 유전자 이상으 로 인해 천연보습인자의 생성이 줄어들고, 각질층의 지질조성이 변하 게 된다. 그로 인해 각질층의 수분함유가 감소되고, 수분손실량 증가 로 건조함, 소양증으로 이어져 염증반응이 유발된다. 염증반응이 일어 나게 되면 대식세포가 활성화되며 nitric oxide (NO), tumor necrosis factor-alpha ( $\mathrm{TNF}-\alpha)$, interleukin (IL), prostaglandin (PG)와 같 은 염증성 매개체들의 생성이 증가된다 (Lee et al., 2017; Yong et al., 2018; Han, 2021). 피부에 염증이 유발되면 구진, 모세혈관 확장 증, 홍조, 아토피 등이 유발되어 피부질환으로 확장된다(Sandilands et al., 2009). 따라서 본 연구에서는 피부 진정 기능성 소재로서의 가 능성을 확인하기 위하여 남원·지리산권에서 재배된 허브식물 라벤더, 레몬그라스, 페퍼민트 3 종을 선별하여 진정에 주요 효능인 항산화, 피부장벽, 보습, 항염증 효능을 종합적으로 확인하고자 실험을 수행하 였다.

라벤더는 체내 유입 시 도파민, 노어 아드레날린, 세로토닌 등의 신경전달물질들과 상호작용을 통해 통증을 감소시키는 효능이 최근 재조명되었다(Park \& Lee, 2019). 향 이외에도 아토피와 같은 피부질 환의 증상을 완화시키고, 상처치유에도 효능(Anderson et al., 2000) 이 있어 자운고의 구성원료 중 하나이다. 레몬그라스는 다양한 폴리페 놀을 함유하고 있는 허브 중 하나이며, 항산화, 항염증, 항균의 효과가 있는 것으로 보고되고 있다. 또한 레몬그라스의 피부 보습과 장벽에 대한 효능이 최근 밝혀졌다(So et al., 2019). 페퍼민트는 항산화효능 이 있으며(Pavlic et al., 2021), menthol등과 같이 매우 다양한 화학적 성분들을 가지고 있어 항염증을 비롯한 항균 및 항암 등에 탁월한 효 능이 있다고 알려져 있다(Skalicka-Wozniak \& Walasek, 2014).

본 연구에서는 고성능액체크로마토그래피를 사용한 19 종 페놀성 화합물 동시분석방법을 통해 라벤더, 레몬그라스, 페퍼민트의 지표(유 효) 성분을 분석하였다. 또한 DPPH radical소거능을 통한 항산화 효 능을 검증하였으며, 피부장벽 주요인자 fillaggrin과 involucrin, 피부 내 수분 함유에 영향을 미치는 히알루론산 합성 효소(hyaluronic acid synthase, HAS)의 발현량을 real time-PCR을 통하여 검증하였고,
LPS로 유발된 염증을 가라앉히는 항염증 효능을 검증하여 진정에 영 향을 미치는 요소를 종합적으로 판단하여 라벤더, 레몬그라스, 페퍼 민트가 가지는 진정 효능을 밝히고, 이들의 화장품 원료로의 가능성을 제안하고자 한다.

\section{Methods}

\section{1. 실험재료}

본 연구에서 사용한 라벤더, 레몬그라스, 페퍼민트는 2020년 5월에 서 10월 사이에 전라북도 남원시 일대에서 뿌리를 제외한 지상부 전 체를 채취하여 사용하였다. 채취한 원물은 $40^{\circ} \mathrm{C}$ 에서 $72 \mathrm{~h}$ 건조(CT160 ; Cooltop, Korea)한 후 $4^{\circ} \mathrm{C}$ 에서 보관, 유지하며 실험에 사용하였 다. 실험에 사용한 라벤더, 레몬그라스, 페퍼민트의 학명, 수확시기, 채취 부위, 재배지역은 Table 1과 같다.

\section{2. $50 \%$ 에탄올추출물 시료 제조}

건조된 라벤더, 레몬그라스, 페퍼민트를 분쇄기(HMF-3600TG; Hanil, Korea)를 이용하여 분쇄한 후, 물 $1 \mathrm{~L}$ 와 에탄올 $1 \mathrm{~L}$ 를 혼합한 $50 \%$ 에탄올에 분쇄물 $100 \mathrm{~g}$ 을 혼합하여 $80^{\circ} \mathrm{C}$ 에서 $4 \mathrm{~h}$ 동안 추출하였 다. 추출물은 부직포와 종이 여과지를 이용하여 3 회 여과하였으며, 여과된 추출물은 감압농축기(R-100; BUCHI, Flawil, Switzerland)를 이용하여 $60^{\circ} \mathrm{C}$ 에서 농축하고, 동결건조기(MCFD8508; IlshinBiobase Co., Ltd., Korea)를 이용하여 동결 건조하였다.

\section{Phenolic compounds에 대한 HPLC 분석}

라벤더, 레몬그라스, 페퍼민트 에탄올 추출물의 19종 phenolic compounds 함량 분석은 high performance liquid chromatography (e2695; Waters Co., USA)를 이용하여 함량을 분석하였다. 19 종에 대한 표준품은 $1 \mathrm{mg}$ 취하여 $50 \%$ 에탄올 $1 \mathrm{~mL}$ 에 용해하였고, $100 \mu \mathrm{L}$ 씩 분주, 혼합하여 사용하였다. 시료는 $10 \mathrm{mg}$ 을 $50 \%$ 에탄올 $1 \mathrm{~mL}$ 에 용해하여 사용하였으며, 19 종 표준품과 시료는 $10 \mu \mathrm{L}$ 를 HPLC 에 주입하고 $0.8 \mathrm{~mL} / \mathrm{min}$ 속도로 분석하였다. 이동상으로는 water ( $0.1 \%$ formic acid)와 Acetonitrile( $0.1 \%$ formic acid)를 사용하였 다. Column은 shim-pack VP-ODS (4.6 mm I.D. $\times 250 \mathrm{~mm} \mathrm{L,} 5$ $\mu \mathrm{m})$ (Shimadzu, Japan)를 이용하여 흡광도 $280 \mathrm{~nm}$ 에서 분석하였 다. 분석에 사용된 19 종의 표준품(Sigma-Aldrich, USA)의 성분명과 retention time (RT), 최대흡수파장은 Table 2에 나타내었다.

Table 1. Botanical name, scientific name, used parts, harvest time, and collection area in lavender, lemongrass, and peppermint

\begin{tabular}{|c|c|c|c|c|}
\hline Botanical name & Scientific name & Used parts & Harvest time & Collection area \\
\hline Lavender & Lavandula angustifolia Mill. & Aerial part & early-Jul & Unbong-eup, Namwon-si \\
\hline Lemongrass & Cymbopogon citratus (DC.) Stapf & Aerial part & early-Oct & Unbong-eup, Namwon-si \\
\hline Peppermint & Mentha $x$ piperita L. & Aerial part & late-May & Songdong-myeon, Namwon-si \\
\hline
\end{tabular}



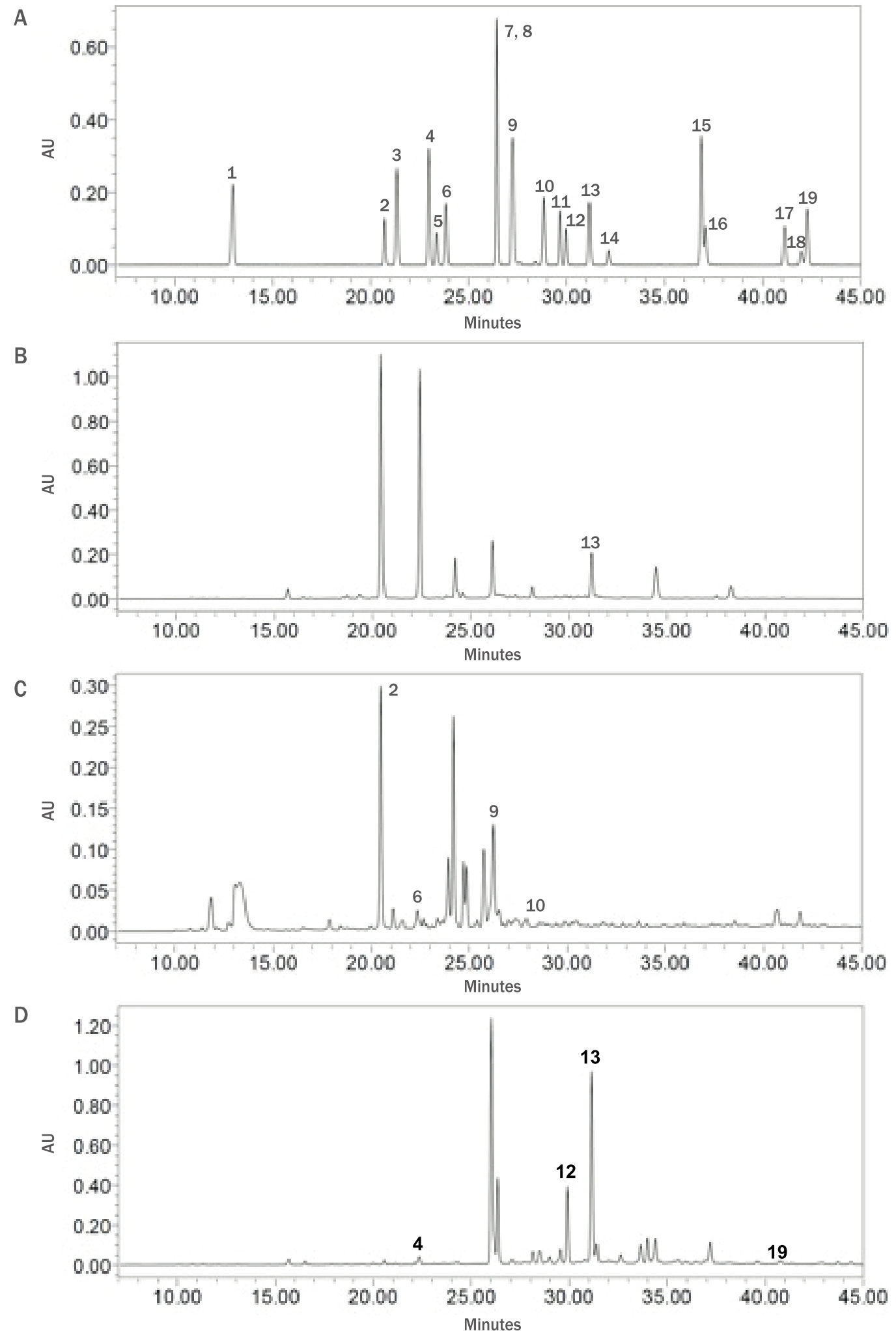

Figure 1. HPLC chromatogram of (A); 19 standard phenolic compounds (Refer to Table 2 for each number), (B); Lavender, (C); Lemongrass, (D); peppermint ethanol extracts with detection at $280 \mathbf{~} \mathbf{m}$.

1: gallic acid, 2: chlorogenic acid, 3: methyl gallate, 4: caffeic acid, 5: EGCG, 6: syringic acid, 7: rutin, 8: ellagic acid, 9: p-coumaric acid, 10: ferulic acid, 11: astragalin, 12: quercitrin hydrate, 13: rosmarinic acid, 14: myricetin, 15: luteolin, 16: quercetin, 17: apigenin, 18: kaempferol, 19: hesperetin. 


\section{DPPH 라디칼 소거 활성 측정}

2,2-diphenyl-1-picrylhydrazyl(DPPH) 라디컬 소거 활성은 Blios (Blois, 1958) 법을 변형하여 측정하였다. 일정 농도로 희 석한 시료 $2.5 \mu \mathrm{L}$ 에 $10 \mu \mathrm{M} \mathrm{DPPH}$ (Sigma-Aldrich) 용액 247.5 $\mu \mathrm{L}$ 를 혼합하고, 차광하여 실온에서 $20 \mathrm{~min}$ 반응시킨 후 ELISA Reader (Bio-Rad, Herciles, USA)를 사용하여 $517 \mathrm{~nm}$ 에서 측 정하였다. $\mathrm{DPPH}$ 의 흡광도가 $50 \%$ 감소할 때 나타나는 시료의 농 도를 구하였으며, 각 시료는 3 회 반복 실험을 실시하였다. 양성 대조군은 L-ascorbic acid (Amresco, USA)을 사용하였다.

\section{5. 세포주 및 세포배양}

인간 피부각질형성세포주(HaCaT)와 마우스 대식세포(Raw 264.7)는 한국세포주은행(Korean Cell Line Bank, Korea)에 서 분양 받아 사용하였다. 각 세포를 $56^{\circ} \mathrm{C}$ 에서 $30 \mathrm{~min}$ 동안 열 처리된 fetal bovine serum (Merck Millipore, Burlington, USA) $10 \%$ 와 항생제인 penicillin/streptomycin (Gibco Life Technologies, Carlsbad, CA, USA)를 함유한 Dulbescco's modified Eagle's media (Welgene, Korea)를 사용하여 $37^{\circ} \mathrm{C}$ 에 서 배양하였다.

\section{6. 실시간 중합효소연쇄반응(qRT-PCR)을 통한 유전자 발현}

6well plate에 $\mathrm{HaCaT}$ 세포를 $8 \times 10^{5}$ cells로 분주한 후 $24 \mathrm{~h}$ 동 안 배양하고, FBS 미포함 DMEM 배지로 2 번 세척한 후 FBS 미포 함 $\mathrm{DMEM}$ 배지로 교체하고 라벤더, 레몬그라스, 에탄올추출물을 $100 \mu \mathrm{g} / \mathrm{mL}$ 의 농도로 $48 \mathrm{~h}$ 동안 처리하였다. 세포에서 $\mathrm{RNA}$ 를 추 출하기 위해 Tri-reagent (RNAisoPLUS, Takara, Ostu, Japan)을 사용하였으며, 세포에 Tri-reagent $1 \mathrm{~mL}$ 을 넣고 $15 \mathrm{~s}$ 동안 vortex 한 후, $15,000 \mathrm{rpm}$ 에서 $15 \mathrm{~min}$ 동안 원심분리하였다. 원심분리 한 시료에 Chloroform $200 \mu \mathrm{L}$ 을 넣고 $20 \mathrm{~s}$ 동안 vortex한 후 다시 원 심 분리하여 상층액을 획득하였다. 수득한 상층액과 동량의 차가운 isopropanol을 첨가하고, 상온에서 $10 \mathrm{~min}$ 간 반응시킨 뒤, 15,000 $\mathrm{rpm}$ 에서 $20 \mathrm{~min}$ 동안 원심 분리하여 RNA 침전물을 얻었다. RNA 침전물을 $75 \%$ 에탄올로 씻은 후, 침전물을 2-3 $\mathrm{min}$ 간 실온에서 건 조시키고 $0.1 \% \mathrm{DEPC}$ water에 녹였다. RNA 농도는 Evolution 260 bio UV-Vis spectrophotometer (Thermo Fisher Scientific Inc., USA)를 이용하여 $260 \mathrm{~nm}$ 에서 측정하였고, Reverse transcription kit인 RNA to CDNA EcoDry Premix (Takara Bio Inc., Japan)를 이용하여 $1 \mu \mathrm{g}$ 의 $\mathrm{RNA}$ 로 $\mathrm{cDNA}$ 를 합성하였다. 합성된 $\mathrm{cDNA}$ 를 멸 균된 3 차 증류수로 5 배 희석한 후 실시간 PCR은 Fast Start DNA master SYBR Green I kit (Roche, Mannheim, Germany)를 사용

Table 2. Retention time and maximum absorbance wavelength of 19 standard phenolic compounds

\begin{tabular}{llcccccc}
\hline NO. & Compound & $\mathrm{RT}^{1)}(\mathrm{min})$ & $\lambda_{\max }(\mathrm{nm})$ & NO. & Compound & $\mathrm{RT}^{1)}(\mathrm{min})$ & $\lambda_{\max }(\mathrm{nm})$ \\
1 & Gallic acid & 12.577 & 216,271 & 11 & Astragalin & 29.025 & 265,347 \\
2 & Chlorogenic acid & 20.371 & 214,325 & 12 & Quercitrin hydrate & 29.269 & 255,348 \\
3 & Methyl gallate & 20.731 & 215,272 & 13 & Rosmarinic acid & 31.046 & 329 \\
4 & Caffeic acid & 22.224 & 215,323 & 14 & Myricetin & 31.358 & 253,363 \\
5 & EGCG & 22.665 & 274 & 15 & Luteolin & 35.872 & 347 \\
6 & Syringic acid & 22.999 & 216,274 & 16 & Quercetin & 36.078 & 255,363 \\
7 & Rutin & 26.018 & 255,354 & 17 & Apigenin & 39.750 & 267,336 \\
8 & Ellagic acid & 26.124 & 210,310 & 18 & Kaempferol & 40.587 & 265,363 \\
9 & p-Coumaric acid & 26.583 & 253,363 & 19 & Hesperetin & 10.267 & 284 \\
10 & Ferulic acid & 27.828 & 215,323 & & & & \\
\hline
\end{tabular}

${ }^{1)} \mathrm{RT}$, retention time.

Table 3. Primer of quantitative real-time polymerase chain reaction related skin barrier and hydration gene expressions

\begin{tabular}{|c|c|c|c|c|c|c|c|}
\hline Gene & $\begin{array}{l}\text { NCBI Reference } \\
\text { Sequence }\end{array}$ & Species & $\begin{array}{l}\text { Forward/ } \\
\text { Reverse }\end{array}$ & Sequences $\left(5^{\prime} \rightarrow 3^{\prime}\right)$ & CDS & Location & Size (bp) \\
\hline HAS2 & NM_005328.2 & human & $\begin{array}{l}\mathrm{F} \\
\mathrm{R}\end{array}$ & $\begin{array}{l}\text { GCAGTGTAAGATATTGGATGGC } \\
\text { CCCATAAATTCTTGATTGTACCAATCTTC }\end{array}$ & $539-2197$ & $\begin{array}{l}13051326 \\
14551427\end{array}$ & 151 \\
\hline HAS3 & AF234839.1 & human & $\begin{array}{l}\mathrm{F} \\
\mathrm{R}\end{array}$ & $\begin{array}{l}\text { TGTCCAGATCCTCAACAAGTACGA } \\
\text { CTGGAGGAGGCTGTTGC }\end{array}$ & $157-1818$ & $\begin{array}{c}888911 \\
10441028\end{array}$ & 157 \\
\hline Filaggrin & AH002947.2 & human & $\begin{array}{l}\mathrm{F} \\
\mathrm{R}\end{array}$ & $\begin{array}{l}\text { GGCTAAGTGAAAGACTTGAAGAGA } \\
\text { AATAGACTATCAGTGGTGTCATAGG }\end{array}$ & $2586-4929$ & $\begin{array}{l}37513774 \\
39073883\end{array}$ & 157 \\
\hline Involucrin & АH002845.2 & human & $\begin{array}{l}F \\
R\end{array}$ & $\begin{array}{l}\text { GGCAGCTGAAGTACCTGGAA } \\
\text { TCCAGCTGCTCCAGTTG }\end{array}$ & $964-2721$ & $\begin{array}{l}18051824 \\
19731957\end{array}$ & 169 \\
\hline$\beta$-actin & NM_001101.4 & human & $\begin{array}{l}\mathrm{F} \\
\mathrm{R}\end{array}$ & $\begin{array}{l}\text { CACTGTGCCCATCTACG } \\
\text { CTTAATGTCACGCACGATTTC }\end{array}$ & $193-1320$ & $\begin{array}{l}675691 \\
831811\end{array}$ & 157 \\
\hline
\end{tabular}


하여 Light Cycler 2.0 (Roche, Germany)에서 증폭하였으며, 사용 된 Primer와 PCR조건은 Table 3, 4와 같다(So et al., 2019). 유전 자의 정량분석은 Light Cycler Software 4.0 (Roche, Mannheim, Germany)을 이용하였으며, 피부장벽에 대한 양성대조군은 Calcium Chloride(Sigma-Aldrich Co., St. Louis, MO, USA) 2 mM을, 피부 보습에 대한 양성 대조군은 all-trans Retinoic acid (Sigma-Aldrich USA) $1 \mu \mathrm{M}$ 을 사용하였다.

\section{Pro-inflammatory Cytokine IL-6 생성 억제 활성 측정}

RAW264.7 세포를 $5 \times 10^{4}$ cells/well씩 96 well plate에 접종하고, $10 \% \mathrm{FBS}$ 가 첨가된 $\mathrm{DMEM}$ 배지에서 $18 \mathrm{~h}$ 동안 전 배양하였다. 세포 에 라벤더, 레몬그라스, 페퍼민트의 에탄올추출물을 $25,50,100 \mu \mathrm{g} /$ $\mathrm{mL}$ 의 세 가지 농도로 각각 처리하고, $1 \mathrm{~h}$ 뒤 $1 \mu \mathrm{g} / \mathrm{mL}$ 의 LPS를 추 가로 처리한 뒤 $24 \mathrm{~h}$ 재 배양하였다. 배양액 내의 $\mathrm{IL}-6$ cytokine 분 비량을 ELISA kit (R\&D System Inc., USA)를 이용하여 정량하였으 며, standard에 대한 표준곡선의 상관계수값은 0.9 이상이었다.

\section{Nitric oxide 생성 억제 평가}

RAW264.7 세포를 $5 \times 10^{4}$ cells/well씩 96 well plate에 접종하고, $10 \% \mathrm{FBS}$ 가 첨가된 $\mathrm{DMEM}$ 배지에서 $18 \mathrm{~h}$ 동안 전 배양하였다. 세포 에 라벤더, 레몬그라스, 페퍼민트의 에탄올추출물을 $25,50,100 \mu \mathrm{g} /$ $\mathrm{mL}$ 의 세 가지 농도로 각각 처리하고, 1 시간 뒤 $1 \mu \mathrm{g} / \mathrm{mL}$ 의 LPS를 추가로 처리한 뒤 $24 \mathrm{~h}$ 재 배양하였다. 세포배양 상등액 $100 \mu \mathrm{L}$ 와 Griess 시약(Promega, USA) $100 \mu \mathrm{L}$ 를 96 well plate에서 혼합하여 $10 \mathrm{~min}$ 동안 반응시킨 후 $540 \mathrm{~nm}$ 에서 흡광도를 측정하였다. 생성된
$\mathrm{NO}$ 의 양은 Griess 시약을 이용하여 세포배양액 중 존재하는 $\mathrm{NO}_{2}{ }^{-}$의 형태로 측정하였고, standard로는 sodium nitrite (Promega, USA) 를 사용하였다.

\section{Results and Discussion}

\section{1. 라벤더, 레몬그라스, 페퍼민트 에탄올추출물의 페놀성 화합물 분석}

라벤더와 레몬그라스, 페퍼민트 에탄올추출물에 대한 페놀성 화 합물을 검출하고자 고성능액체크로마토그래피(high performance liquid chromatography, HPLC) 를 이용한 19 종 페놀성 화합물의 동시 분석을 수행하였다(So et al., 2019). 19 종의 표준물질을 이용 하여 혼합 표준원액을 조제하고 표준검량선을 작성하였으며, 이때 19 종 표준물질을의 상관계수(correlation coefficient, $\mathrm{R}^{2}$ ) 값은 모두 0.9 이상의 직선성을 보였다. 표준물질과 각 시료 간 UV spectrum 의 비교 분석과 각 시료 검출선에 대한 retention time을 고려하여 표준물질과의 일치 여부를 확인하였고, 이를 이용한 19 종 표준물질 의 동시 분석 HPLC 크로마토그램을 Figure $1 \mathrm{~A}$ 에 나타내었다(Lee et al., 2020). 허브 3종의 19 종 페놀성 화합물의 동시분석 결과는 Table 5 와 같이 라벤더 에탄올추출물에서는 rosmarinic acid가 8.26 $\mathrm{mg} / \mathrm{g}$ 검출되었으며(Figure $1 \mathrm{~B})$, 레몬그라스 에탄올추출물에서는 chlorogenic acid $9.93 \mathrm{mg} / \mathrm{g}, p$-coumaric acid $1.02 \mathrm{mg} / \mathrm{g}$, ferulic acid $0.46 \mathrm{mg} / \mathrm{g}$, syringic acid $0.24 \mathrm{mg} / \mathrm{g}$ (Figure 1C), 페퍼민트 에 탄올추출물에서는 caffeic acid $0.84 \mathrm{mg} / \mathrm{g}$, hesperetin $0.30 \mathrm{mg} / \mathrm{g}$,

Table 4. PCR conditions of quantitative real-time polymerase chain reaction related skin barrier and hydration gene expressions

\begin{tabular}{|c|c|c|c|c|c|}
\hline Gene & Hot start & Denaturation & Annealing & Extension & Cycles \\
\hline HAS2 & $95^{\circ} \mathrm{C}, 10 \mathrm{~min}$ & $95^{\circ} \mathrm{C}, 15 \mathrm{~s}$ & $60^{\circ} \mathrm{C}, 10 \mathrm{~s}$ & $72{ }^{\circ} \mathrm{C}, 10 \mathrm{~s}$ & 45 \\
\hline HAS3 & $95^{\circ} \mathrm{C}, 10 \mathrm{~min}$ & $95^{\circ} \mathrm{C}, 15 \mathrm{~s}$ & $60^{\circ} \mathrm{C}, 10 \mathrm{~s}$ & $72^{\circ} \mathrm{C}, 10 \mathrm{~s}$ & 45 \\
\hline Filaggrin & $95^{\circ} \mathrm{C}, 10 \mathrm{~min}$ & $95^{\circ} \mathrm{C}, 15 \mathrm{~s}$ & $60^{\circ} \mathrm{C}, 10 \mathrm{~s}$ & $72^{\circ} \mathrm{C}, 10 \mathrm{~s}$ & 45 \\
\hline Involucrin & $95^{\circ} \mathrm{C}, 10 \mathrm{~min}$ & $95^{\circ} \mathrm{C}, 15 \mathrm{~s}$ & $64^{\circ} \mathrm{C}, 10 \mathrm{~s}$ & $72^{\circ} \mathrm{C}, 10 \mathrm{~s}$ & 45 \\
\hline$\beta$-actin & $95^{\circ} \mathrm{C}, 10 \mathrm{~min}$ & $95^{\circ} \mathrm{C}, 15 \mathrm{~s}$ & $60^{\circ} \mathrm{C}, 10 \mathrm{~s}$ & $72^{\circ} \mathrm{C}, 10 \mathrm{~s}$ & 40 \\
\hline
\end{tabular}

Table 5. Profile of phenolic compounds in lavender, lemongrass, and peppermint ethanol extracts

\begin{tabular}{llc}
\hline Botanical name & Phenolic compund & Amount $(\mathrm{mg} / \mathrm{g})$ \\
Lavender & Rosmarinic acid & $8.26 \pm 0.19$ \\
Lemongrass & Chlorogenic acid & $9.93 \pm 0.15$ \\
& $p$-Coumaric acid & $1.02 \pm 0.06$ \\
& Ferulic acid & $0.46 \pm 0.04$ \\
& Syringic acid & $0.24 \pm 0.04$ \\
Peppermint & Caffeic acid & $0.84 \pm 0.02$ \\
& Hesperetin & $0.30 \pm 0.01$ \\
\hline
\end{tabular}


A

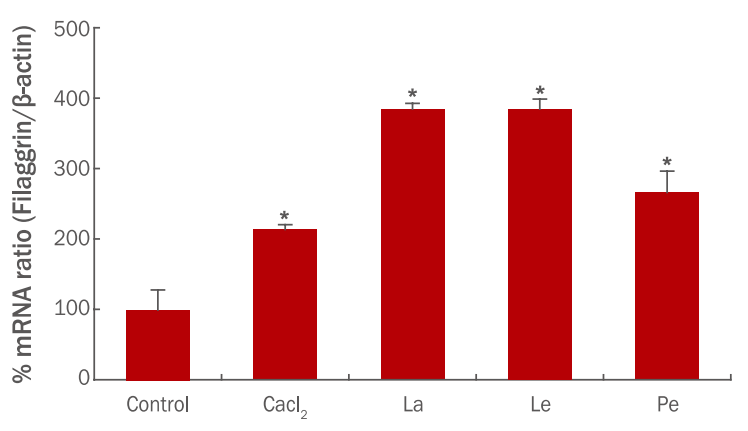

B

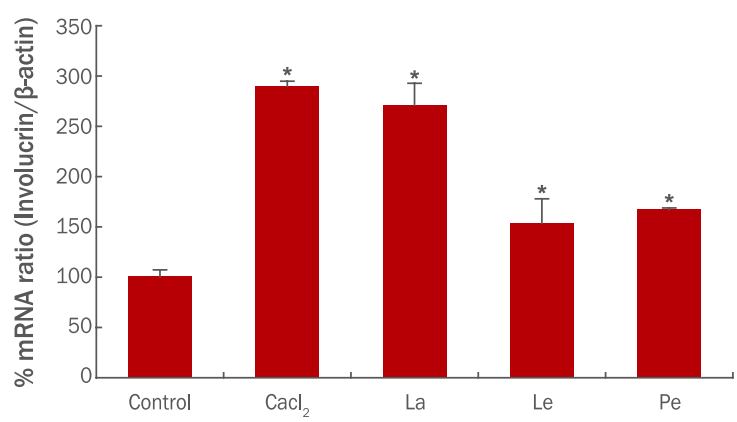

Figure 2. Expression of filaggrin (A) and involucrin (B) mRNA in lavender, lemongrass and peppermint ethanol extracts.

Value of Pearson's correlation coefficients is calculated by correlation option in data analysis tools using Tukey-Kramer multiple comparison test. significant at the $5 \%$ levels of probability ( ${ }^{*} p<0.05$ versus control). ATRA, all-trans retinoic acid; La, Lavender; Le, Lemongrass; Pe, Peppermint.

rosmarinic acid $36.57 \mathrm{mg} / \mathrm{g}$, quercitin hydrate $2.36 \mathrm{mg} / \mathrm{g}$ 이 검출 되었다(Figure 1D).

동시분석에 이용한 19 종의 페놀성화합물 중에서 총 8 가지가 검 출되었는데, 이 중 라벤더와 페퍼민트에서 모두 검출된 rosmarinic acid는 항산화, 미백, 보습 효과가 있다고 보고되어 있으며(Oliveira et al., 2013), 항염증 효능 또한 밝혀진 바 있다(Rocha et al., 2015). 레몬그라스에서 가장 많은 양이 검출된 chlorogenic acid의 경우 항 산화, 미백, 주름, 보습 효과가 있을 뿐만 아니라, 장벽에 관여하 는 지방산 구성과 염증완화에도 효능이 보고된 바 있다(Lee et al., 2020, Naveed et al., 2018). 또한 레몬그라스에서 추가로 검출된 syringic acid는 항염증(Lu et al., 2015) 효과, $p$-coumaric acid와 ferulic acid는 항산화, 보습, 항염증(Chaudhary et al., 2019) 효과가 있다고 보고된 바 있다. 페퍼민트에서 추가로 검출된 caffeic acid는 항산화, 보습, 항염증(Yang et al., 2013) 효과, quercitrin hydrate와 hesperetin은 항산화, 항염증(Lee et al., 2015; Parhiz et al., 2015) 효과가 보고되어 있다. 이후, 남원·지리산권에서 재배된 허브 3 종의 페놀성 화합물 분석 결과를 바탕으로 항산화, 보습, 피부장벽, 그리 고 항염증의 효능이 기대되어 연구를 진행하였다.
2. 라벤더, 레몬그라스, 페퍼민트 에탄올추출물의 항산화 효능 라벤더와 레몬그라스, 페퍼민트의 에탄올추출물이 가지는 항산화 능력을 측정하기 위하여 2,2-diphenyl-1-picrylhydrazyl (DPPH) 라디칼 소거능을 측정하였다(Table 6). 실험결과 $\mathrm{DPPH}$ 라디컬 소거 능은 라벤더, 페퍼민트, 레몬그라스 순으로 나타났으며 $50 \%$ 소거활 성을 나타내는 $\mathrm{SC}_{50}$ 값은 양성대조군인 L-ascorbic acid가 $5 \mu \mathrm{g} / \mathrm{mL}$ 일 때, 각각 $40 \mu \mathrm{g} / \mathrm{mL}, 53 \mu \mathrm{g} / \mathrm{mL}, 83 \mu \mathrm{g} / \mathrm{mL}$ 로 확인되었다(Table 6). 국내 자생 식물 86 종 메탄올추출물의 항산화 활성에 대한 연구 에서 86 종의 $\mathrm{DPPH} \mathrm{SC}_{50}$ 값 분포가 $5.8-472 \mu \mathrm{g} / \mathrm{mL}$ 에 분포하고, 43 위에 해당하는 사위질빵 메탄올추출물이 $115 \mu \mathrm{g} / \mathrm{mL}$ 의 $\mathrm{SC}_{50}$ 값 을 가지는 것으로 볼 때(Rim et al., 2000), 각각이 $100 \mu \mathrm{g} / \mathrm{mL}$ 이하 인 $\mathrm{SC}_{50}$ 값을 가지는 라벤더, 페퍼민트, 레몬그라스는 모두 평균보다 높은 DPPH 라디칼 소거능을 가지므로 우수한 항산화 효능을 가지는 것으로 판단할 수 있다.

\section{3. 라벤더, 레몬그라스, 페퍼민트 에탄올추출물의 피부장벽 개선} 효과

피부보호를 피부의 장벽기능은 각질층 구조체를 통해서 나타나 며(Youm, 2013) 각질형성세포의 분화가 시작되면서 involucrin,

Table 6. DPPH radical scavenging activity in lavender, lemongrass, and peppermint ethanol extracts

\begin{tabular}{lc}
\hline Botanical name & $\mathrm{DPPH}_{\left(\mathrm{SC}_{50}{ }^{1)}, \mu \mathrm{g} / \mathrm{mL}\right)}$ \\
- & Ascorbic acid, $5 \pm 0.33$ \\
Lavender & $40 \pm 0.15^{*}$ \\
Lemongrass & $83 \pm 1.40^{*}$ \\
Peppermint & $53 \pm 2.73^{*}$ \\
\hline
\end{tabular}

"Value of Pearson's correlation coefficients is calculated by correlation option in data analysis tools using Tukey-Kramer multiple comparison test. significant at the $5 \%$ levels of probability $(p<0.05$ versus ascorbic acid). Values are expressed as means $\pm \operatorname{SD}(n=3)$.

${ }^{1)} \mathrm{SC}_{50}$, half maximal scavenging concentration; $\mathrm{SC}_{50}$ values were calculated from regression lines using different concentrations in triplicate experiments. 
A

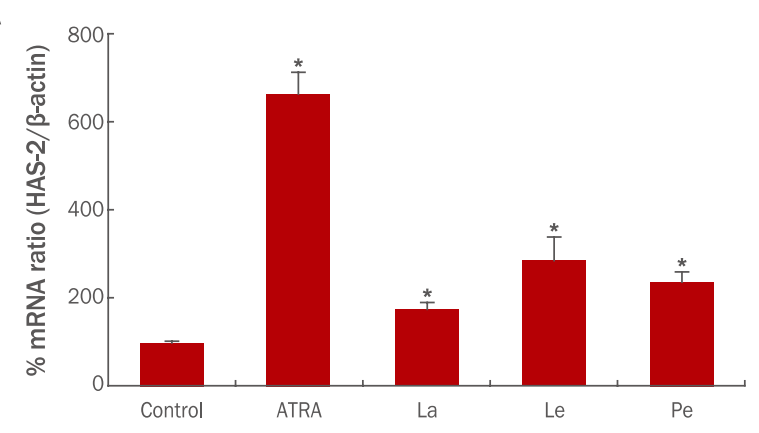

B

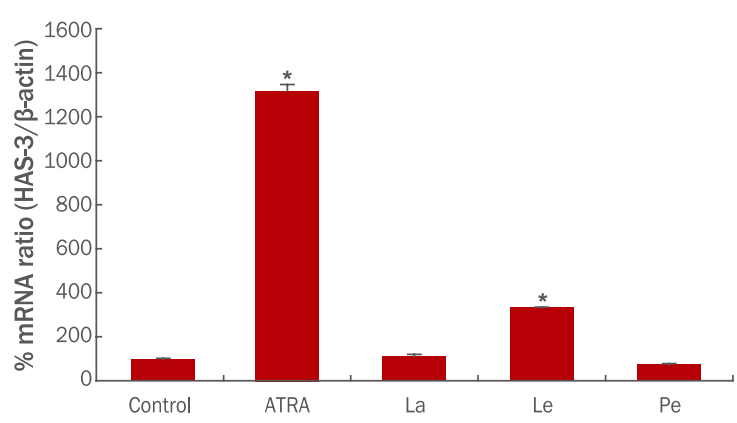

Figure 3. Expression of HAS-2 (A) and HAS-3 (B) mRNA in in lavender, lemongrass and peppermint ethanol extracts.

Value of Pearson's correlation coefficients is calculated by correlation option in data analysis tools using Tukey-Kramer multiple comparison test. significant at the $5 \%$ levels of probability $\left({ }^{*} p<0.05\right.$ versus control). ATRA, all-trans retinoic acid; La, Lavender; Le, Lemongrass; Pe, Peppermint.

cornifin, loricrin, filaggrin 등의 피부 장벽과 관련된 유전자들의 발 현이 증가하고 이들이 결합하여 각질층의 피부장벽기능의 가장 중 요한 기능을 담당하는 각질세포막을 형성하게 된다(Kwon et al., 2007). 또한 피부장벽의 손상이 일어나게 되면 피부 내 표피의 칼 슘이온농도의 변화와 지질합성 및 층판소체분비의 증가, 지질이중 막 형성으로 손상을 회복하게 되지만(Lee \& Chung, 1999), 피부장 벽 기능이 떨어지게 되면 피부 건조증으로 이어지게 되며 아토피와 같은 질환으로 유발될 확률이 높아진다(Kim \& Jeong, 2012). 라벤 더, 레몬그라스, 페퍼민트 에탄올추출물이 피부장벽에 미치는 영향 을 확인하기 위해서 사람 피부각질형성세포주인 $\mathrm{HaCaT}$ 세포에 라벤 더와 레몬그라스, 페퍼민트의 에탄올 추출물 $100 \mu \mathrm{g} / \mathrm{mL}$ 을 $48 \mathrm{~h}$ 동 안 처리하고 real-time $\mathrm{PCR}$ 을 이용하여 피부장벽의 지표 유전자인 filaggrin과 involucrin의 mRNA 발현을 측정하였다(Figure 2).

실험 결과, 양성대조군인 $\mathrm{CaCl}_{2} 2 \mathrm{mM}$ 에서 filaggrin 발현 2.14 배 증가 시, 라벤더 3.85 배, 레몬그라스 3.85 배, 페퍼민트 2.67 배로 라벤더, 레몬그라스, 페퍼민트 3 종 모두 양성대조군에 비해 증가한 것을 확인하였다(Figure $2 \mathrm{~A}$ ). Involucrin의 경우 양성대조군인 $\mathrm{CaCl}_{2}$ 에서 대조군 대비 2.9 배 증가한 것에 비해 라벤더 2.71 배, 레몬그라 스 1.53 배, 페퍼민트 1.67 배로 증가하여 양성대조군보다는 낮지만 대조군 대비 라벤더, 페퍼민트, 레몬그라스 순으로 유의적으로 증가 된 결과를 확인하였다(Figure $2 \mathrm{~B}$ ). 결과적으로 라벤더, 레몬그라스, 페퍼민트 모두 피부장벽에 대한 유전자의 발현을 증가시키므로 피부 장벽 개선효과를 가져다 줄 수 있다고 판단된다.

\section{4. 라벤더, 레몬그라스, 페퍼민트 에탄올추출물의 보습 효능}

피부보습을 유지하는 히알루론산(hyaluronic acid)은 hyaluronic acid synthase, HAS)에 의해 생성된다. $H A S$ 유전자 발현의 증가 는 피부의 표피에 위치하는 기저층, 유극층에서 히알루론산의 보다 많은 합성으로 이어지게 되고 증가한 히알루론산에 의해 피부의 보
습력이 증가된다(Kang et al., 2015). 앞서 수행한 남원·지리산권 에서 재배된 3 종의 라벤더, 레몬그라스, 페퍼민트 에탄올추출물의 페놀성 화합물 분석을 통해서 3 종의 추출물에 포함된 유효성분들 이 보습력의 향상에 도움이 되리라 판단되어 다음의 실험을 진행하 였다.

피부각질형성세포주인 $\mathrm{HaCaT}$ 세포에 라벤더와 레몬그라 스, 페퍼민트의 에탄올 추출물 $100 \mu \mathrm{g} / \mathrm{mL}$ 을 $48 \mathrm{~h}$ 동안 처리하 고 Real-time PCR을 이용하여 각질형성세포에서 생성된다고 알 려진 $H A S-2$ 와 $H A S-3$ 의 $\mathrm{mRNA}$ 의 발현을 확인하였다(Figure 3). $H A S-2$ 는 $H A S-1$ 과 함께 피부의 fibroblast에서 발현되며, $H A S-3$ 는 피부의 keratinocyte에서 발현된다고 알려져 있다(Saito et al., 2011). $H A S-2$ 의 발현은 레몬그라스 $100 \mu \mathrm{g} / \mathrm{mL}$ 에서 2.87 배, 페퍼민트 $100 \mu \mathrm{g} / \mathrm{mL}$ 에서 2.38 배, 라벤더 $100 \mu \mathrm{g} / \mathrm{mL}$ 에서 1.76 배로 레몬그라스, 페퍼민트, 라벤더 순으로 증가하였으며, 이 때 사용된 양성대조군은 ATRA $2 \mu \mathrm{M}$ 로 HAS-2가 6.67 배 증가하 였다(Figure 3A). HAS-3의 발현은 레몬그라스 $100 \mu \mathrm{g} / \mathrm{mL}$ 에서 3.36 배, 라벤더 $100 \mu \mathrm{g} / \mathrm{mL}$ 에서 1.15 배, 페퍼민트 $100 \mu \mathrm{g} / \mathrm{mL}$ 에서 0.77 배로 레몬그라스, 라벤더, 페퍼민트 순으로 증가하였으 며, 양성대조군인 ATRA $2 \mu \mathrm{M}$ 는 $H A S-3$ 가 13.43 배 증가하였다 (Figure 3B). HAS-3은 레몬그라스의 경우 증가된 것으로 볼 수 있 으나, 라벤더와 페퍼민트에서는 유의적으로 증가하지는 않은 것으 로 나타났다. 따라서, $\mathrm{HAS}-2$ 는 평균중량 $2000 \mathrm{kDa}$ 이상인 고분자 히알루론산 생성에 관여하고, HAS-3는 평균 중량 200-2000 kDa 의 저분자 히알루론산 생성에 기여한다는 연구결과(Itano, 2002)를 미루어 보았을 때, 라벤더, 레몬그라스, 페퍼민트 에탄올추출물은 주로 고분자 히알루론산의 생성에 관여하여 피부 내부의 수분보유 량을 증가시켜 피부 보습 효능을 가져다 주리라 판단된다.

\section{5. 라벤더, 레몬그라스, 페퍼민트 에탄올추출물의 항염증 효능}


A

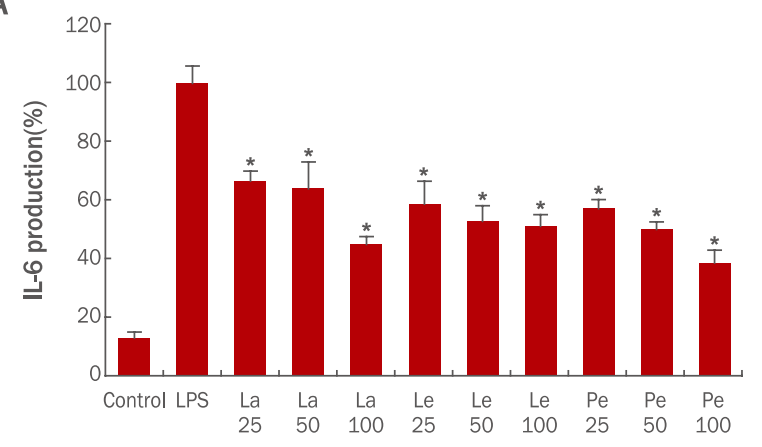

B

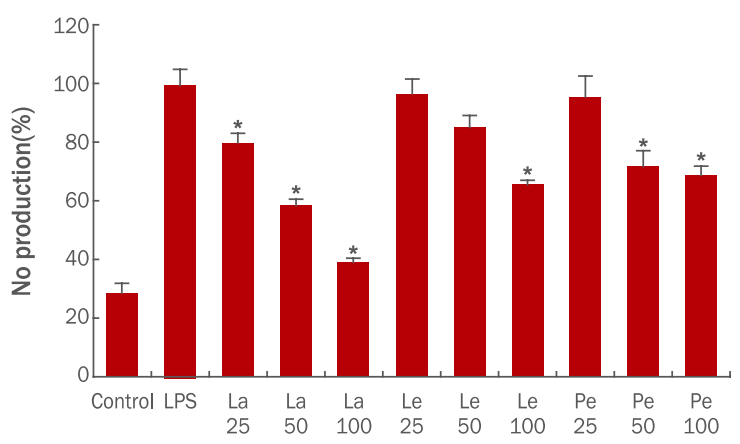

4. II-6 (A) and NO (B) production in in lavender, lemongrass and peppermint ethanol extracts.

Value of Pearson's correlation coefficients is calculated by correlation option in data analysis tools using Tukey-Kramer multiple comparison test. significant at the $5 \%$ levels of probability $\left({ }^{*} p<0.05\right.$ versus LPS treated). LPS, Lipopolysaccharide; La, Lavender; Le, Lemongrass; Pe, Peppermint; 25, 25 g/mL; 50, $50 \mu \mathrm{g} / \mathrm{mL} ; 100,100$ gg/mL.

진정 화장품 소재로서의 효능을 검증하기 위해 항산화, 피부장 벽, 보습 효능에 이어 항염증 효능 평가를 수행하였다. 다양한 원 인에 의한 피부이상반응으로 피부장벽이 손상되게 되면 피부에 서 사이토카인(cytokine)이 분비되고 장벽손상이 꾸준히 지속되 어 사이토카인이 오랜 시간 피부에 분비되게 되면 염증과 같은 피 부에 좋지 않은 결과로 이어질 수 있다(Jin \& Lee, 2014). 염증 반 응이 일어나기 위해서는 피부내 다양한 인자들이 관여하게 되는 데, 염증성 사이토카인 중에서는 $\mathrm{TNF}-\alpha$ 와 $\mathrm{IL}-1 \beta, \mathrm{IL}-6$ 와 같은 proinflammatory cytokines이 주를 이루며, PEG2와 NO와 같은 친염증성 매개물도 염증반응을 유발한다고 알려져 있다. 대식세포 에서 LPS와 같은 자극에 의하여 $\mathrm{IL}-6$ 와 같은 사이토카인이 증가 하고, 염증성 매개물인 $\mathrm{NO}$ 가 증가하여 염증 반응이 유발되는 것은 기존의 연구에서도 잘 알려져 있다(Xie et al., 2012). 따라서 본 연 구에서는 쥐 유래 대식세포인 Raw 264.7 세포에 LPS를 $1 \mu \mathrm{g} / \mathrm{mL}$ 처리한 후, 라벤더, 레몬그라스, 페퍼민트 에탄올추출물을 25,50 , $100 \mu \mathrm{g} / \mathrm{mL}$ 세가지 농도로 처리하여 염증성 사이토카인인 IL-6 와 친염증성 매개물 $\mathrm{NO}$ 의 발현을 확인하였다(Figure 4). 그 결과, $\mathrm{IL}-6$ 는 라벤더, 레몬그라스, 페퍼민트에서 모두 농도의존적 효능을 나타냈으며, $100 \mu \mathrm{g} / \mathrm{mL}$ 일 때 페퍼민트 에탄올 추출물은 $61 \%$, 라 벤더 에탄올추출물은 $55 \%$, 레몬그라스 에탄올추출물은 $49 \%$ 로 페 퍼민트, 라벤더, 레몬그라스 순으로 사이토카인 발현을 억제하는 것 으로 확인되었다(Figure 4A). 또한, 염증성 매개물인 $\mathrm{NO}$ 의 발현 역 시 라벤더, 레몬그라스, 페퍼민트에서 모두 농도의존적 효능을 보였 으며, $100 \mu \mathrm{g} / \mathrm{mL}$ 일 때 라벤더 에탄올추출물은 $61 \%$, 레몬그라스 에탄올추출물은 $34 \%$, 페퍼민트 에탄올 추출물은 $31 \%$ 로 라벤더, 레 몬그라스, 페퍼민트 순으로 $\mathrm{NO}$ 의 생성을 억제하는 것으로 확인되 었다(Figure 4B).

\section{Conclusion}

본 연구에서는 라벤더, 레몬그라스, 페퍼민트 $50 \%$ 에탄올 추출 물의 유효성분을 정량, 분석하고 항산화, 피부장벽, 보습, 항염증 효능을 검증하여 라벤더, 레몬그라스, 페퍼민트를 코로나 시대의 주요 키워드인 '진정' 관련 천연화장품 원료로서 제안하고자 하였 다.

먼저, 라벤더, 레몬그라스, 페퍼민트의 $50 \%$ 에탄올 추출물을 $\mathrm{HPLC}$ 를 이용한 19종 페놀성화합물 동시분석방법으로 분석하여, 유효한 효능을 보이는 지표성분인 rosmarinic acid 외 7 종의 페놀 성화합물의 선별적 정량과 정성분석을 통해 항산화, 보습, 피부장 벽, 항염증에 효능을 보일 것으로 판단되어 연구을 수행하였다.

항산화 효능 평가 결과 DPPH 라디칼 소거 활성이 라벤더, 레몬 그라스, 페퍼민트 에탄올 추출물에서 모두 우수한 결과를 나타냈으 며 피부장벽과 보습 관련 기전실험을 통해 관련된 인자들의 양성대 조군 대비 높은 발현량을 확인하여 피부장벽 및 피부보습에 상당히 우수한 개선효과를 주리라 판단된다. 또한 항염증 효능평가에서도 염증매개물(NO)과 염증관련 사이토카인(IL-6)의 농도의존적인 감 소를 나타내어 우수한 효능을 보이리라 판단된다.

이러한 실험 결과를 종합하였을 때, 남원·지리산권에서 재배된 라벤더, 레몬그라스, 페퍼민트 허브 3 종의 $50 \%$ 에탄올추출물은 항산화, 피부장벽, 보습, 항염증 효능을 가지며, 이러한 결과를 종 합하여 봤을 때 진정 소재로서의 적용 가능성이 매우 높을 것으로 판단된다. 따라서 향후 남원·지리산권의 라벤더, 레몬그라스 또는 페퍼민트를 활용한 진정 관련 천연화장품의 개발은 마스크 착용 장 기화, 각종 exposome에 의한 노출 등으로 야기된 피부이상반응의 진정 및 chemical phobia로 인해 천연 화장품을 찾는 소비자의 니 즈에 부합할 것으로 사료된다. 


\section{Acknowledgements}

본 연구는 농림축산식품부의 재원으로 농림수산식품 기획평가 원의 농림축산식품연구개발사업(과제번호 317024-5)의 지원에 의해 이루어진 결과로 이에 감사드립니다.

\section{Author's contribution}

JWH conducted anti-inflammatory experiment. BMN conducted analysis by HPLC experiment. SYK conducted antioxidant experiment. YNP prepared research and manuscripts on test methods and resource information. BSL performed the preparation of the samples. JWH and JYH analyzed the data, and compiled tables and figures. JYH supervised the project, and wrote the manuscript with the help of JWH.

\section{Author details}

Jiwon Han (Researcher), Institute of Natural Cosmetic Industry for Namwon, Namwon, Jeollabuk-do 55801, Korea.; Bomi Nam (Researcher), Institute of Natural Cosmetic Industry for Namwon, Namwon, Jeollabuk-do 55801, Korea; Seyul Kim (Researcher), Institute of Natural Cosmetic Industry for Namwon, Namwon, Jeollabuk-do 55801, Korea; Yuna Park (Researcher), Institute of Natural Cosmetic Industry for Namwon, Namwon, Jeollabukdo 55801, Korea; Beom Seok Lee (Researcher), Institute of Natural Cosmetic Industry for Namwon, Namwon, Jeollabuk-do 55801, Korea; Ji Young Hwang (Researcher), Institute of Natural Cosmetic Industry for Namwon, Namwon, Jeollabuk-do, Korea.

\section{References}

Anderson C, Lis-Balchin M, Kirk-Smith M. Evaluation of massage with essential oils on childhood atopic eczema. Phytotherapy Research, 14: 452-456, 2000.

Blois MS. Antioxidant determinations by the use of a stable free radical. Nature, 181: 1199-1200, 1958.

Chaudhary A, Jaswal VS, Choudhary S, Sharma A, Beniwal V, Tuli HS, Sharma S. Ferulic acid: a promising therapeutic phytochemical and recent patents advances. Recent Patents on Inflammation \& Allergy Drug Discovery, 13: 115-123. 2019.

Forslind BO. A domain mosaic model of the skin barrier. Acta
Dermato-Venereologica, 74: 1-6, 1994.

Han JS. Nutritional value and anti-inflammation activity of Misutkaru with added Gryllus bimaculatus powder. Asian Journal of Beauty and Cosmetology, 19: 467-476, 2021.

Itano N, Kimata K. Mammalian hyaluronan synthases. IUBMB Life, 54: 195-199, 2002.

Jin SP, Lee DH. Epidermal structure and skin barrier. The Journal of Skin Research, 16: 5-12, 2014.

Kang, MS, Ha HY, Kim HT. An experimental study on the effect of Angelica acutiloba ethanol extract on hyaluronic acid synthesis. The Journal of Korean Medicine Ophthalmology and Otolaryngology and Dermatology, 28: 32-40, 2015.

Kim HJ, Jeong SK. New in trends skin barrier research. The Journal of Skin Barrier Research, 4: 15-28, 2012.

Kwon YB, Choi DK, Sohn KC, Jeon EK, Nam MS, Lee JH, Kim CD. Effects of colostrum on keratinocyte differentiation and wound healing. Korean Journal of Investigative, 14: 456-450. 2007.

Lee EK, Shin MC, Jung SH. Volatile Compound analysis and anti-oxidant and anti-inflammatory effects of Oenanthe javanica, Perilla frutescens, and Zanthoxylum piperitum essential Oils. Asian Journal of Beauty and Cosmetology, 15: 355-366, 2017.

Lee SH, Chung TS. Understanding the skin barrier. The Journal of Skin Barrier Research, 1: 8-21, 1999.

Lee KJ, Oh YC, Cho WK, Ma JY. Antioxidant and antiinflammatory activity determination of one hundred kinds of pure chemical compounds using offline and online screening HPLC assay. Evidence-Based Complementary and Alternative Medicine, 2015: 165457, 2015.

Lee TB, So YK, Kim SY, Hwang JY. Biological activities of cosmetic material from ten kinds of flower ethanol extracts. Korean Journal of Medicinal Crop Science, 28: 260-275, 2020.

Lin TK, Zhong L, Santiago JL. Anti-inflammatory and skin barrier repair effects of topical application of some plant oils. International Journal of Molecular Sciences, 19: 70, 2018.

Lu CL, Zhu W, Wang DM, Chen WL, Hu MM, Wang M, Xu XJ, Lu CJ. Inhibitory effects of chemical compounds isolated from the rhizome of Smilax glabra on nitric oxide and tumor necrosis factor- $\alpha$ production in lipopolysaccharideinduced RAW264. 7 cell. Evidence-Based Complementary and Alternative Medicine, 2015: 602425, 2015. 
Naveed M, Hejazi V, Abbas M, Kamboh AA, Khan GJ, Shumzaid M, AhmadF, Badazadeh D, FangFang X, ModarresiGhazani F, WenHua L, XiaoHui Z. Chlorogenic acid (CGA): A pharmacological review and call for further research. Biomedicine \& Pharmacotherapy, 97: 67-74. 2018.

Oliveira KB, Palú É, Weffort-Santos AM, Oliveira BH. Influence of rosmarinic acid and Salvia officinalis extracts on melanogenesis of B16F10 cells. Revista Brasileira de Farmacognosia, 23: 249-258. 2013.

Parhiz H, Roohbakhsh A, Soltani F, Rezaee R, Iranshahi M. Antioxidant and anti-inflammatory properties of the citrus flavonoids hesperidin and hesperetin: an updated review of their molecular mechanisms and experimental models. Phytotherapy Research, 29: 323-331, 2015.

Park YS, Lee MK. Meta-analysis of the effects of lavender aromatherapy on pain. Journal of the Korea AcademiaIndustrial Cooperation Society, 20: 300-310, 2019.

Pavlic B, Teslić N, Zengin G, Đurović S, Rakić D, Cvetanović A, Gunes AK, Zeković Z. Antioxidant and enzyme-inhibitory activity of peppermint extracts and essential oils obtained by conventional and emerging extraction techniques. Food Chemistry, 338: 127724, 2021.

Pienimaki JP, Rilla K, Fulop C, Sironen RK, Karvinen S, Pasonen S, Lammi MJ, Tammi R, Hascall VC, Tammi MI. Epidermal growth factor activates hyaluronan synthase 2 in epidermal keratinocytes and increases pericellular and intracellular hyaluronan. Journal of Biological Chemistry, 276: 20428-20435, 2001.

Rawlings AV, Matts PJ. Stratum corneum moisturization at the molecular level: an update in relation to the dry skin cycle. Journal of Investigative Dermatology, 124: 1099-1110, 2005.

Rim YS, Park YM, Park MS, Kim KY, Kim MJ, Choi YH. Screening of antioxidants and antimicrobial activity in native plants. Korean Journal of Medicinal Crop Science, 8: 342-350, 2000.
Rocha J, Eduardo-Figueira M, Barateiro A, Fernandes A, Brites D, Bronze R, Duarte CM, Serra AT, Pinto R, Freitas M, Fernandes E, Silva-Lima B, Mota-Filipe H, Sepodes B. Antiinflammatory effect of rosmarinic acid and an extract of Rosmarinus officinalis in rat models of local and systemic inflammation. Basic \& Clinical Pharmacology \& Toxicology, 116: 398-413, 2015.

Saito S, Takayama Y, Mizumachi K, Suzuki C. Lactoferrin promotes hyaluronan synthesis in human dermal fibroblasts. Biotechnology Letters, 33: 33-39, 2011.

Sandilands A, Sutherland C, Irvine AD, McLean WI. Filaggrin in the frontline: role in skin barrier function and disease. Journal of Cell Science, 122: 1285-1294, 2009.

Skalicka-Wozniak K, Walasek M. Preparative separation of menthol and pulegone from peppermint oil (Mentha piperita L.) by high-performance counter-current chromatography. Phytochemistry Letters, 10: xciv-xcviii, 2014.

So YK, Hwang JY, Kim HW, Jo HN, Lee TB. Skin hydration and skin barrier effects of Cymbopogon citratus and Perilla frutescens extracts. Journal of the Society of Cosmetic Scientists of Korea, 45: 225-235, 2019.

Xie C, Kang J, Li Z, Schauss AG, Badger TM, Nagarajan S, Wu T, Wu X. The açaí flavonoid velutin is a potent antiinflammatory agent: blockade of LPS-mediated TNF- $\alpha$ and IL-6 production through inhibiting NF-KB activation and MAPK pathway. The Journal of Nutritional Biochemistry, 23: 1184-1191, 2012.

Yang WS, Jeong D, Yi YS, Park JG, Seo H, Moh SH, Hong S, Cho JY. IRAK1/4-targeted anti-inflammatory action of caffeic acid. Mediators of Inflammation, 2013: 1-12, 2013.

Youm JK. Basic concept of skin barrier. The Journal of Skin Barrier Research, 15: 41-47, 2013.

Yong HJ, Kim GR, Ahn JJ, An IS, Kim YS. Inhibition of apoptosis and anti-inflammatory effects of embelin. Asian Journal of Beauty and Cosmetology, 16: 103-112, 2018. 


\section{국문초록}

\section{남원 · 지리산권 허브 3 종의 피부 진정 효능에 관한 연구}

한지원, 남보미, 김세율, 박유나, 이범석, 황지영*

재단법인남원시화장품산업지원센터, 전라북도 남원시, 한국

목적: 본 연구는 남원·지리산권에서 재배된 라벤더, 레몬그라스, 페퍼민트의 진정 기능성 화장품원료로서의 활용성을 평가하기 위 해 수행되었다. 방법: 남원·지리산권에서 재배된 라벤더, 레몬그라스, 페퍼민트를 $50 \%$ 에탄올로 추출한 추출물로 HPLC를 이용한 19 종 폴리페놀 동시분석을 진행하여 분석하고, 2,2-diphenyl-1-picrylhydrazyl (DPPH)를 통해 항산화 활성을 측정하였다. Realtime PCR을 이용하여 Filaggrin과 Involucrin의 mRNA 발현량 관찰을 통해 피부장벽 개선능을, $H A S-2$ 와 $H A S-3$ 의 mRNA 발현 량 관찰을 통해 보습 능력을 확인하였다. 또한 염증성 사이토카인인 $\mathrm{L}-6$ 와 친염증성매개물 $\mathrm{NO}$ 의 발현량을 확인하여 항염증 효능 을 입증하였다. 결과: 19 종 페놀성화합물 동시분석 결과 라벤더에서 rosmarinic acid, 레몬그라스에서 chlorogenic acid와 syringic acid, $p$-coumaric acid, ferulic acid, 페퍼민트에서 caffeic acid와 quercitin hydrate, rosmarinic acid, hesperetin 성분을 확인하였다. 항산화 효능은 $\mathrm{DPPH}$ 라디칼 소거능으로 확인하였으며 라벤더, 페퍼민트, 레몬그라스 순으로 우수한 효능을 보였다. 피부장벽 관련 유전자인 filaggrin과 involucrin은 라벤더와 레몬그라스, 페퍼민트 3 종 모두에서 무처리군보다 증가되었으며, 보습 관련 유전자인 HAS-2와 HAS-3 역시 라벤더와 레몬그라스, 페퍼민트에서 증가된 양상으로 확인하였다. 또한 라벤더, 레몬그라스, 페퍼민트 모 두 염증 관련 사이토카인 $\mathrm{L}-6$ 와 염증 매개물인 $\mathrm{NO}$ 의 결과에서 농도의존적으로 억제 효능을 나타내었다. 결론: 남원·지리산권에 서 재배된 라벤더, 레몬그라스, 페퍼민트의 에탄올추출물은 항산화, 피부장벽, 보습, 항염증에 대한 우수한 효능을 보이므로 진정 화장품의 천연원료로써 활용가능하리라 판단된다.

핵심어: 라벤더, 레몬그라스, 페퍼민트, 진정, 항염증

본 연구는 농림축산식품부의 재원으로 농림수산식품기술기획평가원의 농생명산업기술개발사업(과제번호: $317024-5)$ 의 지원에 의해 이루어진 결과로 이에 감사드립니다.

\section{참고문헌}

강민서, 하헌용, 김희택. 일당귀 에탄올 추출물의 Hyaluronic Acid 합성 효과에 대한 실험적 연구. 한방안이비인후피부과 학회지, 28: 32-40, 2015.

권유빈, 최대경, 손경철, 전은경, 남명수, 이증훈, 김창덕. 각질형성세포 분화 및 상처치유에 대한 초유의 효과. 대한피부 연구학회지, 14: 45-50, 2007.

박양숙, 이미경. 라벤더향기요법이 통증에 미치는 효과에 대한 메타분석. 한국산학기술학회논문지, 20: 300-310, 2019. 소양강, 황지영, 김현우, 조하늘, 이태범. 레몬그라스와 자소엽 추출물의 피부보습 및 피부장벽에 관한 연구. 대한화장품학 회지, 45: 225-235, 2019.

용희정, 김규리, 안진정, 안인숙, 김영삼. Embelin의 세포사멸 억제 및 항염 효능. 아시안뷰티화장품학술지, 16: 103112, 2018.

이승헌, 정태석. 피부장벽의 이해. 한국피부장벽학회지, $1:$ 8-21, 1999.

이은경, 신민철, 정숙희. 미나리, 깻잎, 초피 정유의 향기성분 분석과 항산화 및 항염 효과. 아시안뷰티화장품학술지, 15: 355-366, 2017.

이태범, 소양강, 김세율, 황지영. 화장품 소재로서의 꽃 10 종 에탄올추출물 생리활성 특성연구. 한국약용작물학회지, $28:$ 260-275, 2020. 
Skin Soothing Effect of Three Herbs from the Namwon-Mt.Jiri Regions

임요섭, 박영민, 박문수, 김길용, 김명조, 최용화. 국내 자생 식물의 항산화 및 항미생물 활성 탐색. 한국약용작물학회지, 8: 342-350, 2020.

한정순. 그릴루스 비마클루투스 분말 첨가 미숫가루의 영양평가와 항염증 활성. 아시안뷰티화장품학술지, 19: 467-476, 2021. 


\section{中文摘要}

\section{来自南原-智异山地区的三种草药的皮肤舒缓效果}

韓址瑗，南寶美，金世栗，朴柔娜，李範夿，黃智暎*

(财) 南原市化妆品产业支援中心，全罗北道南原市，韩国

目的：评估在南原-智异山地区种植的薰衣草、柠檬草和薄荷作为舒缓化妆品原料的可行性。方法: 通过高效液 相色谱 (HPLC)对南原-智异山地区种植的薰衣草、柠檬草和薄荷的 $50 \%$ 乙醇提取样品 19 种同时进行多酚分析。 使用 2,2-diphenyl-1-picrylhydrazyl (DPPH) 测量抗氧化活性；使用实时PCR，通过观察丝聚蛋白和外皮蛋白 的mRNA 表达水平确认皮肤屏障功能的改善, 并通过HAS-2和 HAS-3的mRNA 表达确认保湿能力。通过确认炎 性细胞因子 IL-6 和促炎介质一氧化氮 (NO) 的表达水平来验证抗炎功效。结果: 同时分析19种酚类化合物结果显 示：确认薰衣草中含有rosmarinic acid；柠檬草中含有chlorogenic acid、syringic acid、p-coumaric acid、 ferulic acid；并鉴定出来自薄荷的caffeic acid、quercitin hydrate、rosmarinic acid、hesperetin。抗氧化 功效由DPPH自由基清除证实，以薰衣草、薄荷、柠檬草的顺序显示出优异的功效。与未处理组相比，薰衣草、 柠檬草和薄荷中聚丝蛋白和外皮蛋白、皮肤屏障相关基因的增加更多。HAS-2 和 HAS-3 也被证实在薰衣草、柠 檬草和薄荷中增加。薰衣草、柠檬草和薄荷都表现出对IL-6和NO的浓度依赖性抑制。结论: 在南原-智异山地区 栽培的薰衣草、柠檬草和薄荷提取物具有优异的抗氧化、皮肤屏障、保湿和抗炎作用, 因此可以考虑用作舒缓 化妆品的天然原料。

关键词: 薰衣草, 柠檬草, 薄荷, 舒缓皮肤, 抗炎 
